\title{
Delayed, Frequency-Specific Inhibition in the Cochlear Nuclei of Mice: A Mechanism for Monaural Echo Suppression
}

\author{
Robert E. Wickesberg and Donata Oertel \\ Department of Neurophysiology, University of Wisconsin-Madison, Madison, Wisconsin 53706
}

\begin{abstract}
To understand how auditory information is processed in the cochlear nuclei, it is crucial to know what circuitry exists and how it functions. Previous anatomical experiments have shown that neurons in the deep layer of the dorsal cochlear nucleus (DCN) project topographically to the anteroventral cochlear nucleus (AVCN) (Wickesberg and Oertel, 1988). Because interneurons in the DCN and their targets in AVCN are excited by the same group of auditory nerve fibers, the projection is frequency-specific. Here we report that microinjections of glutamate in the DCN evoke trains of IPSPS in individual, impaled AVCN neurons in brain slices of the cochlear nuclear complex. Only injections along a rostrocaudal band in the DCN, matching the anatomical projection of tuberculoventral neurons, evoke IPSPs; elsewhere, there were no responses to the glutamate. The inhibition is blocked by $0.5 \mu \mathrm{m}$ strychnine. Both bushy and stellate cells are targets of the inhibitory projection. Inhibition in the AVCN is delayed by an additional synaptic delay with respect to the excitation. Delayed, frequency-specific inhibition allows the first wavefront to be transmitted to higher auditory centers by bushy and stellate cells, while following inputs encoding signals of similar frequencies are attenuated at least for the duration of an IPSP. These findings are consistent with results from psychoacoustic experiments and suggest that this circuit provides a source of monaural echo suppression.
\end{abstract}

Echo suppression is an important function in the processing of auditory information in mammals (Wallach et al., 1949; Haas, 1951; Gardner, 1968; McFadden, 1973; Blauert, 1983). In an enclosed area, animals receive sound information directly from the source first, followed by other, somewhat softer and distorted versions of the same sound that have been reflected off the surfaces of the enclosure. We perceive distinct echoes only when they arise from distant surfaces, that is, when their delay is longer than about $30 \mathrm{msec}$. Echoes from nearer surfaces with shorter delays, between 0.6 and about $30 \mathrm{msec}$, are suppressed in the central nervous system. The suppression is not total. Fven echoes with short delays, while not altering the localization of the primary sound, do contribute to the perception of spaciousness

\footnotetext{
Received Sept. 29, 1989; revised Dec. 13, 1989; accepted Dec. 15, 1989.

We thank C. Dizack, T. P. Stewart, I. Siggelkow, J. Eckleberry, J. Meister, and R. Nevel for their willing and skillful help. We also thank C. D. Geisler, S. Greenberg, C. Kung, W. Rhode, B. Sugden, D. Whitlon, and T. C. T. Yin for reading our manuscript. This work was supported by grants ROl NS 17590 and PO1 12732 from the NIH.

Correspondence should be addressed to Dr. Donata Oertel, Department of Neurophysiology, 281 Medical Sciences Building, 1300 University Avenue, University of Wisconsin-Madison, Madison, Wl 53706.

Copyright (C) 1990 Society for Neuroscience $0270-6474 / 90 / 061762-07 \$ 02.00 / 0$
}

(Blauert, 1983). Some of the longer-lasting suppression is binaural. In a relatively large lecture hall, covering one ear unmasks some echoes. In a relatively small room, however, echoes are clearly suppressed even when one ear is covered, showing that echo suppression is in part monaural. One psychoacoustic study (Harris et al., 1963) has proposed the cochlear nuclear complex as a site for monaural echo suppression. The present experiments show that a frequency-specific projection from the deep layer of the dorsal cochlear nucleus (DCN) to the anteroventral cochlear nucleus (AVCN; Wickesberg and Oertel, 1988) is inhibitory. This inhibitory circuit through the DCN could mediate a monaural component of echo suppression.

In the cochlear nuclei, the timing information that is carried in firing patterns of auditory nerve fibers, important for sound localization and speech perception, is conveyed through bushy cells in the AVCN. These are principal neurons in the AVCN specialized to preserve and sharpen the temporal firing patterns of their inputs from auditory nerve fibers (Pfeiffer, 1966; Rhode et al., 1983; Wu and Oertel, 1984; Oertel, 1985; Yin et al., 1988). The other principal cells in the AVCN, the stellate cells, integrate the information from auditory nerve fibers spatially and temporally (Molnar and Pfeiffer, 1968; Rhode et al., 1983; Wu and Oertel, 1984; Oertel, 1985). The processing of auditory nerve inputs in the AVCN depends on the shaping of synaptic responses by the electrical characteristics of cochlear nuclear cells (Oertel et al., 1988) and on neuronal circuits that impinge on the principal cells.

The innervation of the cochlear nuclear complex by auditory nerve fibers is tonotopic (Lorente de Nó, 1933; Rose et al., 1959; Osen, 1970). In each subdivision, fibers that encode high frequencies terminate dorsally and fibers that encode low frequencies terminate ventrally. The large, myelinated auditory nerve fibers contact bushy and stellate cells in the AVCN (Cant and Morest, 1979; Cant, 1981; Tolbert and Morest, 1982). They also terminate in the deep layer of the DCN on fusiform cells and presumably on the tuberculoventral neurons (Kane, 1974), which project to AVCN (Lorente de Nó, 1933, 1981; Feng and Vater, 1985; Wickesberg and Oertel, 1988).

The anatomical organization of the projection from DCN to AVCN was determined with extracellular injections of HRP in the AVCN (Feng and Vater, 1985; Wickesberg and Oertel, 1988). The injections labeled nerve fibers that passed through the injection site. In the midst of the band of labeled auditory nerve fiber terminals in the deep DCN, an isofrequency lamina, a band of cell bodies whose axons passed to the AVCN through the lateral ventral tubercular tract, was also labeled. Since these neurons and their targets in AVCN received inputs from the same auditory nerve fibers, they encode the same frequencies. 


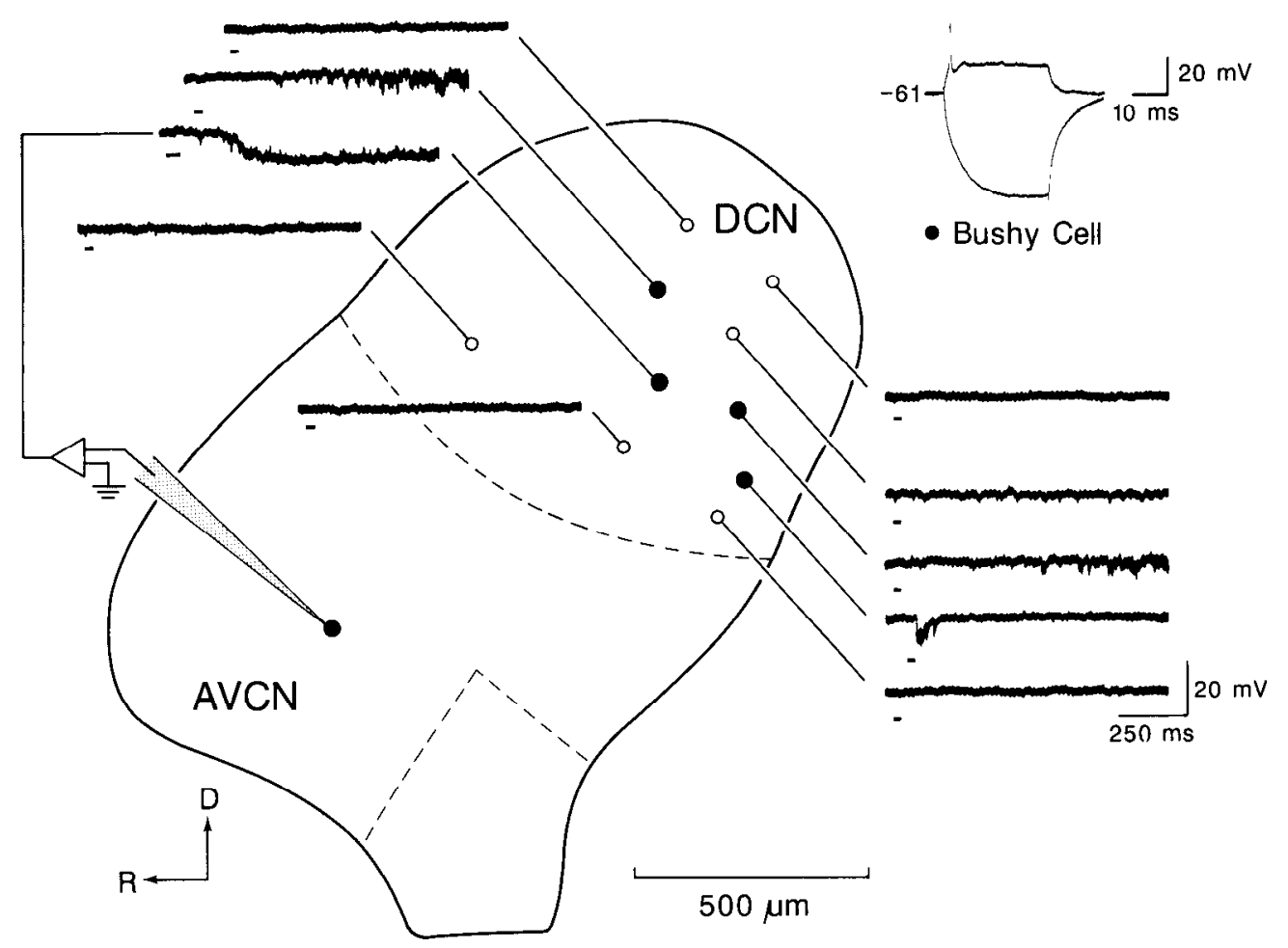

Figure 1. Afferent field in the DCN for a globular bushy cell in AVCN. The traces show the intracellular voltage changes recorded from a single bushy cell located in AVCN (filled circle) and evoked by microinjections of $20 \mathrm{~mm}$ glutamate at various locations (circles) in the DCN. For the locations marked with filled circles, the pulse of glutamatc produced trains of IPSPs. These sites lic in a band running rostrocaudally across the DCN. For locations marked with open circles, dorsal and ventral to this band, there was no response to the glutamate at any depth. One longer $(50 \mathrm{msec})$ pulse evoked trains of IPSPs which summed to produce a hyperpolarizing shift in the membrane potential that lasted 4 sec. Inset shows responses to depolarizing and hyperpolarizing current pulses $( \pm 0.5 \mathrm{nA}, 30 \mathrm{msec})$. Intracellular HRP injections into physiologically characterized cells have shown that a single, small action potential and strong rectification in the depolarizing voltage range are consistently recorded from bushy cells (Wu and Oertel, 1984). The location of the bushy cell in the posterior part of AVCN implies that it is a globular bushy cell. The resting potential of the neuron was $-61 \mathrm{mV}$.

As expected from the tonotopic organization of the AVCN and DCN, dorsal injections in the AVCN label bands of cells located dorsally and ventral injections label bands of neurons located ventrally in the deep DCN. Each tuberculoventral neuron innervates a long stretch of an isofrequency contour in AVCN. The goal of the current experiments was to activate tuberculoventral neurons selectively in order to determine their action and their targets.

\section{Materials and Methods}

Mice of the strain CBA, between 18 and $22 \mathrm{~d}$ old, were decapitated, and the brains removed from the skull in a saline bath. Slice preparations of the most lateral portions of the cochlear nuclear complex were made with a single, approximately parasagittal cut as described previously (Oertel, 1983). The slices were held in a sandwich of gauze in a recording chamber, whose volume was about $0.3 \mathrm{ml}$, in which warm $\left(34.3^{\circ} \mathrm{C}\right)$, oxygenated saline was continuously superfused at a rate of $10 \mathrm{ml} / \mathrm{min}$ (Oertel, 1985). The composition of the saline was $124 \mathrm{~mm} \mathrm{NaCl}, 5 \mathrm{~mm}$ $\mathrm{KCl}, 1.2 \mathrm{mM} \mathrm{KH}_{2} \mathrm{PO}_{4}, 2.4 \mathrm{mM} \mathrm{CaCl}_{2}, 1.3 \mathrm{~mm} \mathrm{MgSO}_{4}, 26 \mathrm{mM} \mathrm{NaHCO}_{3}$, $3 \mathrm{~mm}$ HEPES, and $10 \mathrm{~mm}$ glucose; its $\mathrm{pH}$ was 7.4 when saturated with $95 \% \mathrm{O}_{2}$ and $5 \% \mathrm{CO}_{2}$. Intracellular recordings were made using standard techniques with glass microelectrodes which were filled with $4 \mathrm{M}$ potassium acetate and had resistances between 100 and $200 \mathrm{M} \Omega$.

DCN neurons were activated by pressure ejections of $20 \mathrm{~mm}$ glutamate ( $\mathrm{pH} 7.0)$ from micropipettes using a Picospritzer. Micropipettes had tip diameters of about $10 \mu \mathrm{m}$; a $30 \mathrm{msec}$, 30 psi pressure pulse ejected approximately $70 \mathrm{nl}$. Micropipettes were inserted into the DCN; microinjections were made at 2 or 3 depths at each position. Positions were marked on sketches of the slice preparations using the covering gauze as a landmark. In one experiment $200 \mu \mathrm{M}$ kainate in saline was used instead of glutamate. All drugs were obtained from Sigma.

\section{Results}

By injecting pulses of glutamate into the $\mathrm{DCN}$ at various locations while recording intracellularly from a single AVCN neuron, we determined the positions of DCN neurons which are connected, either directly or indirectly, to the impaled cell in the AVCN. We call that area where glutamate produces a response in the impaled cell its "afferent field." In 5 slices we were able to map afferent fields for 1 bushy cell and 5 stellate cells in AVCN and 1 stellate cell in the rostral posteroventral cochlear nucleus (PVCN). We found that both the bushy and the stellate cells, identified by their electrical properties (Wu and Oertel, 1984), were inhibited by the activation of neurons in the DCN. All showed the same pattern of afferent fields. All cells tested were targets of inhibitory input from the DCN.

The afferent field for a bushy cell is shown in Figure 1. The cell's rectification in the depolarizing voltage range (upper right) identifies it as a bushy cell (Wu and Oertel, 1984). Activation by pulses of approximately $70 \mathrm{nl}$ of $20 \mathrm{~mm}$ glutamate of small groups of cells in a restricted area of the DCN produced a deluge of IPSPs. One longer pulse, approximately $110 \mathrm{nl}$, evoked a steady hyperpolarization. When the stimulating pipette was moved rostrocaudally, inhibitory responses were observed; when it was moved ventrally or dorsally, no responses were observed. The width of the field along the tonotopic axis in the DCN is about $175 \mu \mathrm{m}$. The latency of the glutamate-evoked IPSPs was variable, probably as a result of variability in the distances from 
Figure 2. Afferent fields in the DCN for 2 stellate cells in AVCN reveal the topographic organization of the inhibitory connection between DCN and AVCN. The inhibitory afferent field for the more dorsally located AVCN stellate ccll 2 (squares) was dorsal to the afferent field for the more ventrally located AVCN stellate cell 1 (circles). Filled symbols mark sites where the pulse of glutamate evoked a cascade of IPSPs, while the partially filled symbols indicate that only a few IPSPs were present. In this slice a cut was made across the PVCN which interrupted connections through the PVCN. Inset shows responses of each stellate cell to injected current $( \pm 0.5 \mathrm{nA}, 30 \mathrm{msec})$. The regular firing produced by depolarizing current pulses identifies each of these as stellate cells (Wu and Oertel, 1984). Resting potentials were $-58 \mathrm{mV}$ and $-57 \mathrm{mV}$

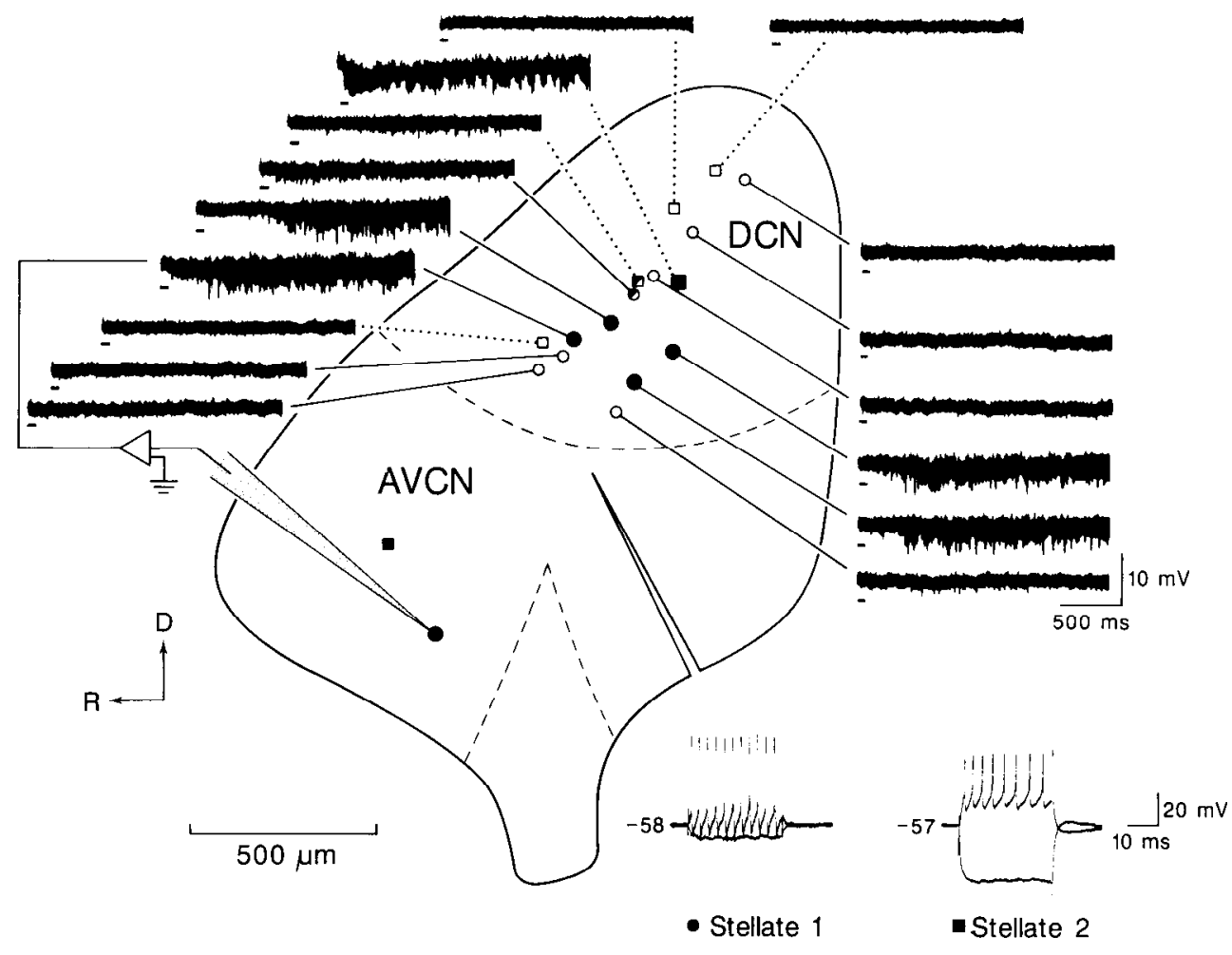

passage. First, the result that only IPSPs, no EPSPs, were activated by the pressure pulses shows that glutamate excited interneurons in the deep DCN without activating the terminals of auditory nerve fibers which lay intermingled with the interneurons. Had auditory nerve fibers been activated antidromically, EPSPs would have been recorded in the bushy cell. Second, if axons of tuberculoventral neurons had been activated, then glutamate application ventral to the afferent field would have evoked IPSPs because these fibers travel ventrally to reach the VCN. Since the afferent fields are restricted not only dorsally but also ventrally, the glutamate does not activate tuberculoventral fibers.

The locations of the afferent fields followed the tonotopic organization of the cochlear nuclear complex. Figure 2 shows the afferent fields for 2 stellate cells in a single slice. The stellate cells were identified by their responses to injected current ( $\mathrm{Wu}$ and Oertel, 1984). Again, a microinjection of glutamate within a narrow band in the DCN produced a barrage of IPSPs in each of the stellate cells. The inhibitory afferent field of stellate cell 1 (filled circles) ran approximately rostrocaudally across the DCN, and was about $150 \mu \mathrm{m}$ wide along the tonotopic axis in the DCN. Stellate cell 2 (squares) was located dorsal to stellate cell 1 (circles); presumably it encoded sounds of higher frequencies. As expected, the afferent field of stellate cell 2 (filled squares) was located more dorsally than that of stellate cell 1 . A pulse of glutamate excited only a small group of neurons with dendrites near the tip of the electrode. The excitation was restricted to an area on the order of $100 \mu \mathrm{m}$ in diameter, because movements of the pipette of about $100 \mu \mathrm{m}$ could result in very different responses. In this slice, a cut was made through the PVCN which interrupted any connections between DCN and AVCN through the PVCN. The fibers mediating the inhibition must have passed through the only remaining route, the lateral ventral tubercular tract.

The projection from the $\mathrm{DCN}$ to the ventral cochlear nucleus
Figure 3. Inhibition from $\mathrm{DCN}$ to $\mathrm{VCN}$ is probably glycinergic. Trains of IPSPs elicited by a pulse of glutamate $(t o p)$ in the DCN were blocked by addition to the superfusing saline of $0.5 \mu \mathrm{M}$ strychnine (middle). The block was reversible (bottom). Traces are from stellate cell 1 , represented with circles in Figure 2. 

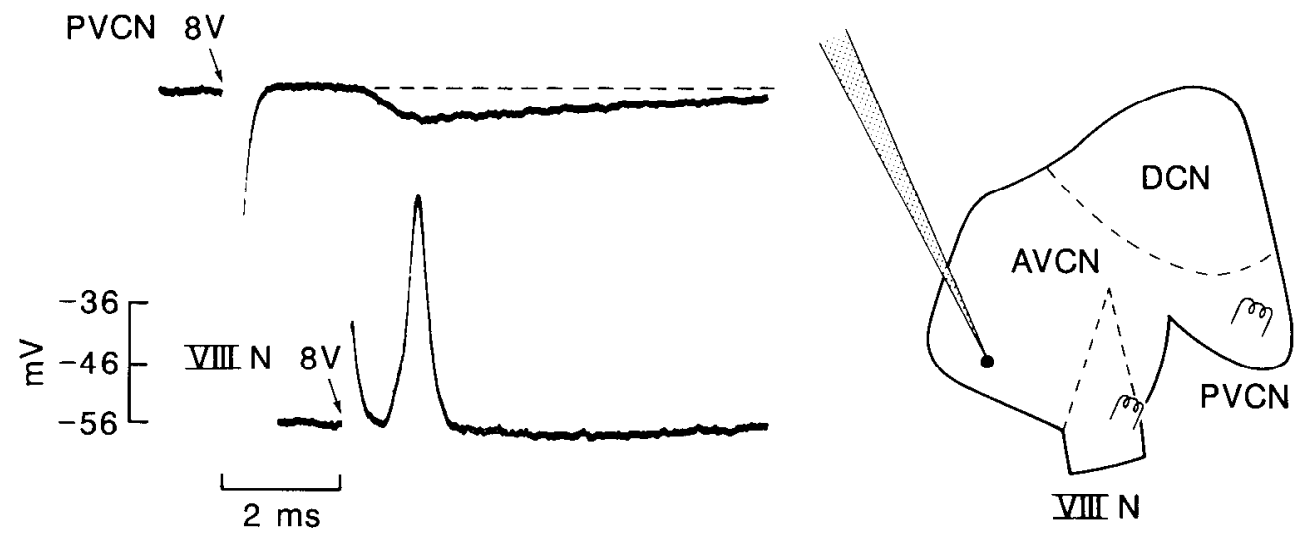

Figure 4. Timing of inhibition through the DCN to the AVCN. A cut through the PVCN (right) allowed the descending branch of the auditory nerve to be stimulated independently of the ascending branch. As shown in a drawing of the slice from which the traces were recorded, the tissue of the PVCN spread apart after the cut was made. The top trace (left) shows an IPSP recorded from a bushy cell in AVCN (filled circle) in response to stimulation of the PVCN. The IPSP is likely to arise by the excitation of an interneuron in the DCN by the descending branch of the auditory nerve. This record shows that activation of the auditory nerve evokes inhibition that can suppress later auditory nerve inputs. The bottom trace shows a suprathreshold response of the same bushy cell to stimulation of the ascending branch of the auditory nerve and it is displayed to show that inhibition is most effective for signals following after a 2 -msec interval.

(VCN) is probably glycinergic. Figure 3 shows that IPSPs evoked by chemical activation of cells in the DCN are reversibly blocked by $0.5 \mu \mathrm{M}$ strychnine, a blocker of glycinergic inhibition (Choi and Fischbach, 1981).

In one experiment, microinjections of $100 \mu \mathrm{M}$ kainate in saline were used to map the afferent fields. The results were the same as when glutamate was used for the mapping. Trains of IPSPS evoked by the kainate lasted longer, sometimes several minutes, than those evoked by glutamate.

The timing of the inhibition through the DCN is shown in Figure 4. The descending branch of the auditory nerve was separated from the ascending branch by a cut through the PVCN. While recording in $\mathrm{AVCN}$, stimulating electrodes on the PVCN could activate connections through the $\mathrm{DCN}$, but not circuits

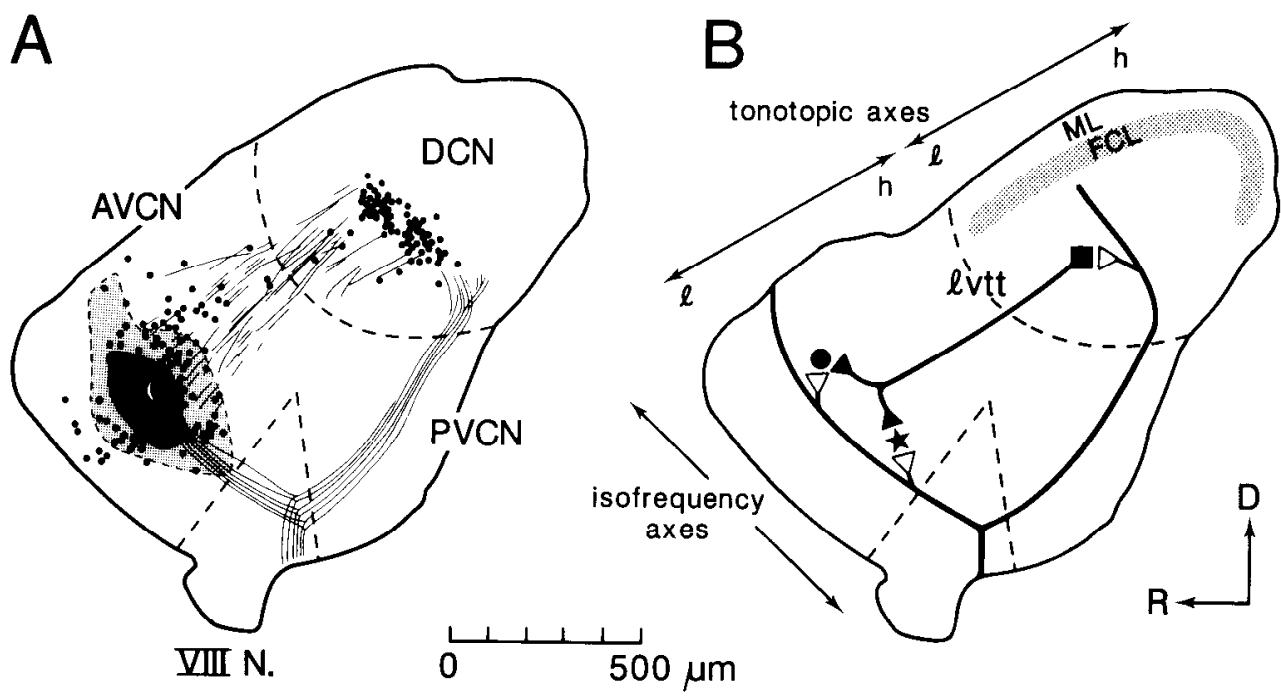

Figure 5. Circuitry in the cochlear nuclear complex. A, Camera lucida reconstruction of the slice in which HRP was injected in AVCN (from Wickesberg and Oertel, 1988) showing the locations of labeled fibers and cell bodies. The labeled neurons in the DCN are found in the band of labeled auditory nerve terminals in the deep DCN. Dashed lines indicate the boundary between the DCN and the VCN and outline the root of the auditory nerve $(V I I I N$.), which separates the anteroventral $(A V C N)$ from the posteroventral cochlear nucleus $(P V C N)$. The anatomical projection of tuberculoventral neurons matches the afferent fields mapped for the VCN neurons. $B$. Diagrammatic representation of circuitry in the cochlear nuclear complex. The auditory nerve fibers from the base of the cochlea, which encode high frequencies, innervate the dorsal portions of the AVCN, PVCN, and DCN, while fibers from the cochlear apex, which encode low frequencies, innervate the ventral portions of these subdivisions. Thus, in each subdivision the cochleotopic map represents high frequencies $(h)$ dorsally and low frequencies $(l)$ ventrally. Isofrequency axes follow the path of the auditory nerve fibers. The DCN, unlike either the AVCN or PVCN, is layered. The outermost is the molecular layer (ML), next is a densely cellular fusiform cell layer $(F C L)$, and most medial is the deep layer, where the auditory nerve terminates. Tuberculoventral neurons (square) all along an isofrequency band in the decp layer send axons through the lateral ventral tubercular tract (lvtt) to innervate that part of the AVCN that receives input from the same auditory nerve fibers, making the projection frequency-specific and topographic. Both bushy (circle) and stellate (star) cells in AVCN are inhibited by tuberculoventral fibers. 
intrinsic to the AVCN. The top trace shows an IPSP recorded in a bushy cell in AVCN in response to a shock to the PVCN. The IPSP began about $2 \mathrm{msec}$ after the PVCN stimulation. Stimulation of the auditory nerve root produced an EPSP with a latency of $0.7 \mathrm{msec}$ (bottom trace). The bottom trace has been shifted so that the stimulus artifacts are $2 \mathrm{msec}$ apart. The peak of the suprathreshold EPSP then occurs at the same time as the trough of the IPSP. A simple interpretation of this experiment is that action potentials in auditory nerve fibers evoke IPSPs that can suppress later inputs from auditory nerve fibers. Suppression is maximal when the interval between signals in auditory nerve fibers is 2 msec; at smaller intervals the suppression has not developed and at larger intervals the suppression is less than maximal.

\section{Discussion}

With mapping of afferents to single cclls, the prescnt expcriments have shown that the location, orientation, and extent of afferent fields match the anatomical organization of the projection from the deep layer of the DCN to the AVCN (Fig. 5A). These experiments also show that both bushy and stellate cells are targets of projections from the DCN. Afferents to both stellate and bushy cells were without exception inhibitory. The pulses of glutamate used to map the afferent fields were found to excite just cell bodies and dendrites in the DCN. In other parts of the brain, glutamate also fails to activate fibers of passage and terminals (Goodchild et al., 1982; Christian and Dudek, 1988). These results indicate that tuberculoventral neurons in the deep DCN inhibit neurons in the AVCN.

The mapping experiments demonstrate that the connection from the DCN to the AVCN is inhibitory but do not show whether the connection is direct or through interneurons. If IPSPs had arisen through a polysynaptic pathway, mediated by excitatory interneurons, then there are 2 alternative possibilities: glutamate might activate excitatory interneurons in the DCN which contact tuberculoventral neurons, or glutamate might activate tuberculoventral neurons, which in turn excite inhibitory interneurons in the VCN. Within the constraints of the anatomical and physiological findings, both hypothetical circuits would function much like the one we have proposed but an additional synaptic delay would be interposed. The simplest explanation for the correspondence between the anatomically and physiologically demonstrated connection is that they are identical (Fig. 5B).

The present results show that in the mouse the inhibition from the deep DCN affects globular bushy cells. Globular bushy cells carry timing information to the superior olivary complex (Harrison and Irving, 1966; Warr, 1972; Tolbert et al., 1982), which is involved in comparing binaural time and intensity information (Goldberg and Brown, 1968; Caird and Klinke, 1983). The inhibition also affects stellate cells, another principal cell type in AVCN. Stellate cells are a heterogeneous group of neurons (Osen, 1969; Brawer et al., 1974; Webster and Trune, 1982; Wu and Oertel, 1984; Smith and Rhode, 1989), some of which project to the DCN (Adams, 1983), the olivary complex (Tolbert et al., 1982), and the inferior colliculi (Osen, 1972; Roth et al., 1978; Adams, 1979; Ryugo et al., 1981; Cant, 1982; Willard and Ryugo, 1983; Oliver, 1987). Although every cell tested in the AVCN was a target of inhibition from the DCN, it is possible that there are subclasses of stellate or bushy cells that do not receive this inhibition.

Inhibition from the DCN to the AVCN can be blocked re- versibly by $0.5 \mu \mathrm{M}$ strychnine, indicating that the inhibition is probably glycinergic. At low concentrations strychnine blocks glycinergic inhibition (Wu and Oertel, 1986). Strychnine binds with high affinity $\left(K_{\mathrm{D}}=4-10 \mathrm{nM}\right)$ to the glycine receptor (Betz and Becker, 1988). At high concentrations ( $\geq 100 \mu \mathrm{M})$ strychnine can block GABA receptors (Choi and Fischbach, 1981) and nicotinic acetylcholine receptors (Gilman et al., 1980), receptors whose amino acid sequences have considerable similarity with those of the glycine receptor subunits (Grenningloh et al., 1987a, b). Immunocytochemical staining has shown that many boutons in the VCN contain glycine (Wenthold et al., 1987) and that VCN neurons have glycine receptors (Wenthold et al., 1988). The deep DCN is not the only source of glycinergic inhibition, however (Godfrey et al., 1977). The finding that disynaptic IPSPs can be recorded in the absence of the DCN shows that some inhibitory interneurons lie within the AVCN. A bushy cell (cell \#14, Wu and Ocrtcl, 1984) labcled with HRP in a slice that contained no DCN responded to shocks to the auditory nerve with late IPSPs and early EPSPs. Late IPSPs are consistently blocked by micromolar strychnine, indicating that there are also inhibitory interneurons in the VCN, like those in the DCN, which are glycinergic (Wu and Oertel, 1986).

Inhibition from the DCN to the VCN can produce monaural echo suppression. The tuberculoventral neurons in the circuit shown in Figure $5 B$ produce an on-frequency inhibitory input to the 2 principal classes of neurons in AVCN. This inhibition occurs after one synaptic delay, minimally $600 \mu \mathrm{sec}$ (Oertel, 1983) and lasts for the duration of an IPSP, about $5 \mathrm{msec}$. The onset of the representation of an acoustic event will not be affected by the negative feedback. Under conditions that activate the interneurons in the DCN, the circuitry allows the first wavefront to be transmitted to higher auditory centers, while following inputs encoding signals of similar frequencies, including echoes, are attenuated.

The responses to sound of the tuberculoventral association cells in vivo are probably of type II (Evans and Nelson, 1973; Young and Brownell, 1976; Young, 1984). Tuberculoventral neurons provide inhibitory inputs to the VCN and they have terminal collaterals within an isofrequency lamina in the DCN (Oertel and Wu, 1989). Type II neurons can be driven antidromically by stimulating electrodes in the VCN (Young, 1980) and they inhibit nearby fusiform cells in the DCN (Voigt and Young, 1980). In the absence of anesthetic, type II cells are activated by tones over a narrow range of frequencies at all sound pressure levels. Firing rates first increase and then decrease with increases of sound pressure level at the characteristic frequency. Tones with frequencies below or above the characteristic frequencies inhibit type II cells, and broadband noise fails to activate these cells (Young and Brownell, 1976; Young and Voigt, 1982). Cells that do not respond to broadband noise are well suited for mediating echo suppression since they would not generally be activated in noisy environments, leaving their targets maximally sensitive to perceive signals over noise.

The existence of circuits in the cochlear nuclei to produce effects similar to echo suppression has been proposed on the basis of results from psychoacoustic experiments. Harris et al. (1963) showed that in a binaural localization experiment, the second of a pair of clicks presented monaurally is suppressed. They argued that this suppression did not occur along the cochlear partition nor was it due to a neural refractory period. They proposed that the suppression was due to a neural gating mechanism that "would have to occur before the place of binaural 
interaction. It seems probable that its position must be at or previous to the superior-olivary complex. In particular, it could occur at the level of the cochlear nucleus."

The timing measured in this psychoacoustical experiment is exactly what would be predicted from our results. Harris et al. (1963) presented double clicks to one ear and asked listeners to adjust the timing of a single click to the contralateral ear so that the image of the sound source was centered. When the first of the double clicks suppressed the second, the timing of the click to the contralateral ear was consistently adjusted to the first. Click intervals of 2 and $4 \mathrm{msec}$ resulted in suppression of the second; intervals of $1 \mathrm{msec}$ or less and of $8 \mathrm{msec}$, the longest interval tested, resulted in no measurable suppression. The timing of inhibition of neurons in the AVCN by tuberculoventral neurons follows the same pattern (Fig. 4). The second of a pair of shocks to the auditory nerve evokes an EPSP in neurons of the AVCN which can be suppressed by an IPSP that was evoked by the first shock. The suppression is most effective when the interval between shocks is about $2 \mathrm{msec}$. It becomes less effective at intervals between about 4 and 6 msec. EPSPs that follow at intervals of $0-1$ msec cannot be affected by the inhibition.

The timing of suppression has also been measured by Zurek (1980) and by Hafter and co-workers (Hafter and Dye, 1983; Hafter et al., 1988). In an investigation of the precedence effect, Zurek (1980) found that interaural time and intensity sensitivity are degraded for a period from approximately 0.5 to $10 \mathrm{msec}$ after onset, with the lowest sensitivity at delays of 2-3 msec. Hafter and co-workers measured the thresholds of detection of interaural time differences for trains of clicks as a function of the number of clicks and the interclick interval. Thresholds were greatest with interclick intervals of 1 and $2 \mathrm{msec}$, reflecting suppression of later clicks in a train at these intervals. Thresholds were lowest with interclick intervals of $5 \mathrm{msec}$ or longer.

Echo suppression is within frequency bands and not across frequency bands. Hafter and his colleagues (Hafter and Wenzcl, 1983; Hafter et al., 1988) found that trains of bandpass-filtered clicks of a single center frequency carry less information when presented at $2.5-\mathrm{msec}$ intervals than at 5 -msec intervals, as if one suppresses the next. Clicks of alternating center frequencies carry as much information when presented at 2.5 -msec intervals as click trains of either frequency alone at 5 -msec intervals. They also concluded that this frequency-specific suppression "takes place in the monaural auditory system at a location peripheral to binaural interaction." Similarly, Divenyi and Blauert (1987) found that echo suppression occurred when the primary sound and the echo had overlapping spectra. These results would be expected from on-frequency inhibition, not sideband inhibition.

The inhibitory feedback from the DCN onto VCN neurons must, by its nature, contribute to the monaural component of echo suppression bccausc inhibition through frequency-specific interneurons driven by primary sounds coincides with excitation by the inputs that encode echoes. Whether echo suppression is the primary function of the circuit cannot be determined by these experiments. Furthermore, echo suppression clearly results from the action of multiple neuronal circuits; echoes can be suppressed monaurally in the cochlear nuclei but binaural echo suppression probably occurs higher up in the auditory pathway (Blauert, 1983).

A projection from the deep DCN to the AVCN has been shown to exist in horseshoe bats (Feng and Vater, 1985). If this circuit is inhibitory and active during echolocation, then bats would be unable to echolocate. It seems, therefore, that the inhibitory circuit through the DCN is inactive during echolocation. Echo suppression might, however, be useful to bats for interpreting communication sounds in caves. Birds, which lack a structure that is homologous to the mammalian DCN (Boord, 1969), generally use auditory information in relatively open environments.

\section{References}

Adams JC (1979) Ascending projections to the inferior colliculus. J Comp Neurol 183:519-538.

Adams JC (1983) Multipolar cells in the ventral cochlear nucleus project to the dorsal cochlear nucleus and the inferior colliculus. Neurosci Lett 37:205-208.

Betz H, Becker C-M (1988) The mammalian glycine receptor: biology and structure of a neuronal chloride channel protein. Neurochem Int 13:137-146

Blauert J (1983) Spatial hearing. Cambridge: MIT.

Boord RL (1969) The anatomy of the avian auditory system. Ann NY Acad Sci 167:186-198.

Brawer JR, Morest DK, Kane EC (1974) The neuronal architecture of the cochlear nucleus of the cat. J Comp Neurol 155:251-300.

Caird D, Klinke R (1983) Processing of binaural stimuli by cat superior olivary complex neurons. Exp Brain Res 52:385-399.

Cant NB (1981) The fine structure of two types of stellate cells in the anterior division of the anteroventral cochlcar nucleus of the cat. Neuroscience 6:2643-2655.

Cant NB (1982) Identification of cell types in the anteroventral cochlear nucleus that project to the inferior colliculus. Neurosci Lett 32: 241-246.

Cant NB, Morest DK (1979) The bushy cells in the anteroventral cochlear nucleus of the cat. A study with the electron microscope. Neuroscience 4:1925-1945.

Choi DW, Fischbach GD (1981) GABA conductance of chick spinal cord and dorsal root ganglion neurons in cell culture. J Neurophysiol 45:605-620.

Christian EP, Dudek FE (1988) Characteristics of local excitatory circuits studied with glutamate microapplication in the CA3 area of rat hippocampal slices. J Neurophysiol 59:90-109.

Divenyi PL, Blaucrt J (1987) On creating a precedent for binaural patterns: when is an echo an echo? In: Auditory processing of complex sounds (Yost WA, Watson CS, eds), pp 147-156. Hillsdale, NJ: Erlbaum.

Evans EF, Nelson PG (1973) The responses of single neurones in the cochlear nucleus of the cat as a function of their location and the anaesthetic state. Exp Brain Res 17:402-427.

Feng AS, Vater M (1985) Functional organization of the cochlear nucleus of rufous horseshoe bats (Rhinolophus rouxi): frequencies and internal connections are arranged in slabs. J Comp Neurol 235:529553.

Gardner MB (1968) Historical background of the Haas and/or precedence effect. J Acoust Soc 43:1243-1248.

Gilman AG, Goodman LS, Gilman A (1980) The pharmacological basis of therapeutics, $p$ 586. New York: Macmillan.

Godfrey DA, Carter JA, Berger SJ, Lowry OH, Matchinsky FM (1977) Quantitative histochemical mapping of candidate transmitter amino acids in cat cochlear nucleus. J Histochem Cytochem 25:417-431.

Goldberg JM, Brown PB (1968) Functional organization of the dog superior olivary complex: an anatomical and electrophysiological study. J Neurophysiol 31:639-656.

Goodchild AK, Dampney RAL, Bandler R (1982) A method for evoking physiological responses by stimulation of cell bodies, but not axons of passage, within localized regions of the central nervous system. J Neurosci Meth 6:351-363.

Grenningloh G, Rienitz A, Schmitt B, Methfessel C, Zensen M, Beyreuther K, Gundelfinger ED, Betz H (1987a) The strychnine-binding subunit of the glycine receptor shows homology with nicotinic acetylcholine receptors. Nature 328:215-220.

Grenningloh G, Gundelfinger E, Schmitt B, Betz H, Darlison MG, Barnard EA, Schofield PR, Seeburg PH (1987b) Glycine vs GABA receptors. Nature 330:25-26.

Haas $H$ (1951) On the influence of a single echo on the intelligibility of speech. Acustica 1:49-58. 
Hafter ER, Dye RH Jr (1983) Detection of interaural differences of time in trains of high-frequency clicks as a function of interclick interval and number. J Acoust Soc Amer 73:644-651.

Hafter ER, Wenzel EM (1983) Lateralization of transients presented at high rates: site of the saturation effect. In: Hearing-physiological basis and psychophysics (Klinke R, Hartmann R, eds), pp 202-208. Berlin: Springer-Verlag.

Hafter ER, Buell TN, Richards VM (1988) Onset-coding in lateralization: its form, site, and function. In: Auditory function (Edelman GM, Gall WE, Cowan WM, eds), pp 647-676. New York: Wiley.

Harris GG, Flanagan JL, Watson BJ (1963) Binaural interaction of a click with a click pair. J Acoust Soc Amer 35:672-678.

Harrison JM, Irving R (1966) Ascending connections of the anterior ventral cochlear nucleus in the rat. J Comp Neurol 126:51-64.

Kane ES (1974) Patterns of degeneration in the caudal nucleus of the cat after cochlear ablation. J Comp Neurol 179:67-92.

I orente de Nó R (1933) Anatomy of the eighth nerve. III. General plans of structure of the primary cochlear nuclei. Laryngoscope 43: 327-350.

Lorente de Nó R (1981) The primary acoustic nuclei. New York: Raven.

McFadden D (1973) Precedence effects and auditory cells with long characteristic delays. J Acoust Soc Amer 54:528-530.

Molnar CD, Pfeiffer RR (1968) Interpretation of spontaneous spike discharge patterns of neurons in the cochlear nucleus. Proc IEEE 56: 993-1004.

Oertel D (1983) Synaptic responses and electrical properties of cells in brain slices of the mouse anteroventral cochlear nucleus. J Neurosci 3:2043-2053

Oertel D (1985) Use of brain slices in the study of the auditory system: spatial and temporal summation of synaptic inputs in cells in the anteroventral cochlear nucleus of the mouse. J Acoust Soc Amer 78: 328-333.

Oertel D, Wu SH (1989) Morphology and physiology of cells in slice preparations of the dorsal cochlear nucleus of mice. J Comp Neurol 283:228-247.

Oertel D, Wu SH, Hirsch JA (1988) Electrical characteristics of cells and neuronal circuitry in the cochlear nuclei studied with intracellular recordings from brain slices. In: Auditory function (Edelman GM, Gall WE, Cowan WM, eds), pp 647-676. New York: Wiley.

Oliver DL (1987) Projections to the inferior colliculus from the anteroventral cochlear nucleus in the cat: possible substrates for binaural interaction. J Comp Neurol 264:24-46.

Osen KK (1969) Cytoarchitecture of the cochlear nuclei in the cat. J Comp Neurol 136:453-484.

Osen KK (1970) Course and termination of the primary afferents in the cochlear nuclei of the cat. Arch Ital Biol 108:21-51.

Osen KK (1972) Projection of the cochlear nuclei on the inferior colliculus in the cat. J Comp Neurol 144:355-372.

Pfeiffer RR (1966) Classification of response patterns of spike discharges for units in the cochlear nucleus: tone-burst stimulation. Exp Brain Res 1:220-235.

Rhode WS, Oertel D, Smith PH (1983) Physiological response properties of cells labeled intracellularly with horseradish peroxidase in cat ventral cochlear nucleus. J Comp Neurol 213:448-463.

Rose JE, Galambos R, Hughes JR (1959) Microelectrode studies of the cochlear nuclei of the cat. Bull Johns Hopkins Hosp 104:211251
Roth GL, Aitkin LM, Andersen RA, Merzenich MM (1978) Some features of the spatial organization of the central nucleus of the inferior colliculus of the cat. J Comp Neurol 182:661-680.

Ryugo DK, Willard FH, Fekete DM (1981) Differential afferent projections to the inferior colliculus from the cochlear nucleus in the albino mouse. Brain Res 210:342-349.

Smith PH, Rhode WS (1989) Structural and functional properties distinguish two types of multipolar cells in the ventral cochlear nucleus. J Comp Neurol 282:595-616.

Tolbert LP, Morest DK (1982) The neuronal architecture of the anteroventral cochlear nucleus of the cat in the region of the cochlear nerve root: electron microscopy. Neuroscience 7:3053-3068.

Tolbert LP, Morest DK, Yurgelun-Todd DA (1982) The neuronal architecture of the anteroventral cochlear nucleus of the cat in the region of the cochlear nerve root: horseradish peroxidase labeling of identified cell types. Neuroscience 7:3031-3052.

Voigt HF, Young ED (1980) Evidence of inhibitory interactions between neurons in dorsal cochlear nucleus. J Neurophysiol 44:76-96.

Wallach H, Newman EB, Rosenzweig MR (1949) The precedence effect in sound localization. Am J Psychol 52:315-336.

Warr WB (1972) Fiber degeneration following lesions in the multipolar and globular areas in the ventral cochlear nucleus of the cat. Brain Res 40:247-270.

Webster DB, Trune DR (1982) Cochlear nuclear complex of mice. Am J Anat 163:103-130.

Wenthold RJ, Huie D, Altschuler RA, Reeks KA (1987) Glycine immunoreactivity localized in the cochlear nucleus and superior olivary complex. Neuroscience 22:897-912.

Wenthold RJ, Parakkal MH, Oberdorfer MD, Altschuler RA (1988) Glycine receptor immunoreactivity in the ventral cochlear nucleus of the guinea pig. J Comp Neurol 276:423-435.

Wickesberg RE, Oertel D (1988) Tonotopic projection from the dorsal to the anteroventral cochlear nucleus of mice. J Comp Neurol 268: 389-399.

Willard FH, Ryugo DK (1983) Anatomy of the central auditory system. In: The auditory psychobiology of the mouse (Willott JF, ed), pp 201-304. Springficld, Hlinois: Thomas.

Wu SH, Oertel D (1984) Intracellular injection with horseradish peroxidase of physiologically characterized stellate and bushy cells in slices of mouse anteroventral cochlear nucleus. J Neurosci 4:15771588.

Wu SH, Oertel D (1986) Inhibitory circuitry in the ventral cochlear nucleus is probably mediated by glycine. J Neurosci 6:2691-2706.

Yin TCT, Carney LH, Joris PX, Smith PH (1988) Enhancement of phase-locking to low frequency tones in some cells of the ventral cochlear nucleus of the cat. Soc Neurosci Abstr 14:648.

Young ED (1980) Identification of response properties of ascending axons from dorsal cochlear nucleus. Brain Res 200:23-37.

Young ED (1984) Response characteristics of neurons of the cochlear nuclei. In: Hearing science (Berlin CI, ed), pp 423-460. San Diego: College-Hill.

Young ED, Brownell WE (1976) Responses to tones and noise of single cells in dorsal cochlear nucleus of unanesthetized cats. J Neurophysiol 39:282-300.

Young ED, Voigt HF (1982) Response properties of type II and type III units in dorsal cochlear nucleus. Hear Res 6:153-169.

Zurek PM (1980) The precedence effect and its possible role in the avoidance of interaural ambiguities. J Acoust Soc Amer 67:952-964. 